\title{
Comparability of cash flow statements: Evidence from Baltic Countries
}

\author{
Vaiva Kiaupaite-Grušniene ${ }^{\mathrm{a}, 1}$ and Lehte Alver ${ }^{\mathrm{b}}$ \\ ${ }^{a}$ Department of Business Administration, Tallinn University of Technology \\ ${ }^{b}$ Department of Business Administration, Tallinn University of Technology
}

\begin{abstract}
Research Question: Whether the adoption of IFRSs has led to the harmonization and comparability of Baltic listed companies' cash flow statements? Motivation: Baker and Barbu (2007) have marked that the adoption of IFRSs in EU is the new phase of international harmonization. However, IFRSs still provide flexibility to financial statement preparers when applying the standards due to explicit options, discretion in interpretation and the need for estimates (Wehrfritz \& Haller, 2014). Measuring the extent to which financial reports of companies are comparable is an important topic. Our research applies $\mathrm{H}$-index and $\mathrm{C}$-index for measuring harmonization of Baltic listed companies' cash flow statements. Idea: We examine the problem of harmonization cash flow statements. Data: The sample contains all companies (in total 33) listed on Nasdaq Baltic market for years 2010-2017. Tools: To measure harmonization and comparability of financial reports $\mathrm{H}$-index for each country was found. C-index was used for finding overall, within-country and between-country harmonization. Findings: While there is a longitudinal consistency in classification choice within each company, there is no consistency among the companies in interest received and paid. Dividend treatment is more consistent and harmonized. Users of financial reports should not expect comparability of cash flow statements of Estonian, Latvian and Lithuanian companies, despite the existence of a single stock exchange, cross-border cultural and economic similarities and de jure harmonization of accounting standards. Contribution: This paper contributes to IFRSs impact analysis, and specifically harmonization and comparability literature, by providing comparative results for Estonia, Latvia and Lithuania in financial statement preparers' classification judgement.
\end{abstract}

1 Corresponding author: Vaiva Kiaupaite-Grušniene, Department of Business Administration, Tallinn University of Technology; Ehitajate tee 5, Tallinn Estonia 19086, tel. +372 5039518, email address: vaiva.kiaupaite-grusniene@taltech.ee 
Keywords: accounting, IFRS, accounting policy choice, classification, cash flow

JEL code: M40, M41, M48, G14

\section{Introduction}

Accounting is complex socio-economic activity that has been an integral part of human civilization for over 4000 years. It is the language of business, which provides quantitative information about companies that is intended to be useful for decision making by stakeholders. The increased globalization of business coupled with improvement in technology, has led to globalization of capital markets and increased international investment, which calls for international accounting practices harmonization. At the same time, there have been impediments in achieving harmonization, due to cultural and economic differences among countries. The use of IFRSs is a major reporting issue worldwide and has been a subject of extensive academic research, as understanding the impact of IFRSs on company's accounting process is important for accountants, auditors, corporate management, investors, lenders, financial analysts, regulators.

The adoption of IFRSs in EU in 2005, following Regulation No. 1606/2002 (also called "IAS-Regulation") aimed to increase the comparability of publicly traded companies' annual reports and is said to have marked the new phase of international harmonization (Baker \& Barbu, 2007). However, IFRSs still provide flexibility to financial statement preparers when applying the standards due to explicit options, discretion in interpretation and the need for estimates (Wehrfritz \& Haller, 2014). Therefore, differences can still be found in IFRSs application from one company to another as well as from country to country. This led to discussion whether IFRSs are applied consistently and whether "de-jure standardization of accounting rules of group accounts of publicly-traded companies in the $\mathrm{EU}$ has also let to de-facto harmony" (Wehrfritz \& Haller, 2014: 196). IFRS application in Central and SouthEastern European countries is discussed by Albu and Albu (2014).

Measuring the extent to which financial reports of companies are comparable is an important topic and deserves the attention of researchers, standard setters and practitioners (Taplin, 2011). Measuring harmony refers to the extent to which different companies use the same accounting method. If policy makers desire harmonization, then it is valuable to quantify the extent to which harmonization has occurred. Taplin (2011) argues that quantifying the extent to which company statements are comparable is valuable even without a formal theoretical framework. The comparability in accounting methods used increases, as companies concentrate more on one alternative method, and Herfindahl or H-index (Roberts, et al, 2008) can measure this concentration. 
Nobes (2006) argues that country specific factors, such as legal system, national financing system, national accounting regime and national culture, may still be relevant in IFRSs reporting, as it influences accountants and their judgements on how the rules are applied. In the recent years, the issues of comparability are of increasing interest to accounting researchers, practitioners and regulators, because of a widespread adoption of IFRSs, the main goal of which is increased quality and comparability of financial reports.

Cash flow statement or Statement of cash flows is a third principal financial statement in corporate financial reports. It presents cash inflows and outflows during a period from operating, investing and financing activities. The information about cash flows of an entity is useful in providing the users of financial statements with basis to analyze company's ability to generate cash and needs for the use of cash. Cash flows from operating activities (CFOA) are interpreted as ability of a company to maintain its current operations while funding future growth. Cash flow and particularly CFOA is used as a basis for business valuation, contracting, and financial analysis (Gordon et al., 2017). Extensive literature focuses on classification shifting in profit or loss statement and balance sheet (statement of financial position), while less focus has been on classification shifting in cash flow statement, prior to IFRSs (Lee, 2012; Gordon et al., 2017). Specifically in terms of cash flow statement, IAS 7 gives financial statement preparers flexibility and allows to classify interest received, interest paid, dividends received and dividends paid as either operating, investing or financing activity, provided they are classified consistently from period to period (IAS 7.31).

This paper contributes to IFRSs impact analysis, and specifically harmonization and comparability literature, by providing comparative results for Estonia, Latvia and Lithuania in financial statement preparers' classification judgement under IFRSs. To the authors' knowledge, all previous researchers have focused on the "old EU" states and no such analysis has been done for the Baltic countries. The study is also beneficial for the users of financial statements, as it draws attention to the fact that a single set of rules does not guarantee similar treatment of items in cash flow statement. Further, it points out that with widespread IFRSs adoption there is a risk that investors are misled into believing that there is more uniformity in reporting, than there actually is in practice (Ball, 2006).

The paper is organized as follows. Section 2 provides literature review and develops hypotheses. Section 3 discusses data and research design. Section 4 presents the findings and discussion of the empirical results. Section 5 concludes the paper.

\section{Literature Review}

\subsection{Concept of accounting harmonization}

Over the past decades there were numerous efforts made by legislators and accounting standard setters to reduce the number of different accounting treatments 
used to account for a particular transaction. To some extent, it has been caused by the perceived needs of capital markets and was intended to facilitate comparison of financial statements of different companies within a country and between countries. To evaluate the success of those harmonization efforts a number of indicators have been devised.

It is important to start with distinguishing the two terms used in international accounting research: "harmonization" and "standardization". The terms tend to be used loosely in accounting literature (Tay \& Parker, 1990), when referring to the efforts required to ensure that similar transactions and events are accounted in a uniform way wherever they took place of were reported. Harmonization is a process by which accounting moves away from diversity in practice, with ending result of state of harmony when all companies use only one of the available methods of accounting, or a very limited number of methods. Proponents of this system argue that harmonization can be achieved through natural processes of changes in culture, economic growth, international trade, etc., which causes national accounting regulators to imitate each other's practices. Some authors refer to de facto or material harmonization, which entails increase in comparability and de jure or formal harmonization, which covers harmonization of regulations. Formal harmonization could lead to material harmonization but could also cause dis-harmonization, if the new standards allow for more options (Canibano \& Mora, 2000; Tay \& Parker, 1990). Standardization is the process by which all companies agree to follow the same or very similar accounting practice, resulting in a state of uniformity. This process, as opposed to harmonization, is more formal and requires regulatory involvement to ensure compliance (Roberts et al., 2008).

The main benefits of harmonization include increasing comparability of financial reports prepared in different countries and providing international investors with decision-useful information, removing barriers for international capital flows by reducing differences in financial reporting requirements for international capital market participants, and reducing financial reporting costs for multinational companies.

The notion of harmony, under this view, is that the process will lead to a situation of maximum harmony with respect to a particular financial statement item when all companies in all countries use the same accounting method. Consequently, harmonization studies are concerned with the similarity of accounting practices of companies.

Harmonization indices are commonly calculated to report the level of harmony of accounting practices. Aisbitt (2001) refers to multiple authors (e.g. Nair \& Frank, 1981; Doupnik \& Taylor, 1985; McKinnon \& Janell, 1984) and states that early attempts to measure harmonization used descriptive statistics and variance analysis 
to evaluate the success of standards (Aisbitt, 2001). Research that is more recent has developed from the work of van der Tas (1988) who suggested quantifying the degree of harmony of financial reporting practices with the Herfindahl index $(\mathrm{H}-$ index) of industrial concentration. $\mathrm{H}$-index is calculated by weighting the relative frequencies of the alternative options against each other. Thus, high relative frequencies have higher weighting and $\mathrm{H}$-index raises when the methods companies are choosing concentrate more on one or a limited number of alternatives. $\mathrm{H}$-index can fluctuate between 0 (no harmony, infinite number of alternatives with same frequency) and 1 (all companies use the same method) (van der Tas, 1988).

Since the indices do not allow for complete comparability of financial reporting practices, van der Tas has created a comparability index (C-index). Expanded version of $\mathrm{C}$-index even allows considering situations where information published in footnotes is reprocessed and appears in financial reports. Archer et al. (1995; 1996) propose that international harmony means, all companies would select all other things being equal, a given accounting method. They explore the mathematics of C-index and show how it can be decomposed into within-country and betweencountry comparability indices. The $\mathrm{C}$-index has been considered the most reliable way of measuring the extent of harmonization but criticisms have been raised as well. Tay and Parker (1990) draw attention to the limiting factors in index interpretation, as when several values of indices are calculated under different circumstances, it is not clear whether observed differences are due to different degrees of harmony or due to sampling variation. Baker and Barbu (2007) quote Krisement (1997) who argues that a number of observations affect C-index and criticizes decomposed index of Archer et al., because the sum of within-country and between-country indices did no equal the overall global C-index (Baker \& Barbu, 2007).

\subsection{IFRSs and harmonization}

Accounting comparability is perceived as a key factor of informative financial reporting and a necessary condition for achieving a common market in EU. It leads to benefits for report users through improvements in information quality and quantity, as well as lower information obtaining costs. It also contributes to more efficient capital market resource allocation and more effective performance evaluation by managers (De Franco et al., 2011). The importance of financial statement comparability across companies is underscored in valuation techniques, such as price multiples, which are extensively used by investment banks and institutional investors. Consequently, standard setters position comparability as a central feature of the financial reporting system. International Accounting Standards Board (IASB) and Financial Accounting Standards Board (FASB) have listed it as most important property of financial accounting information. IFRS Conceptual Framework (QC4) states "if financial information is to be useful, it must be relevant and faithfully represent what it purports to represent. The usefulness of financial 
information is enhanced if it comparable, verifiable, timely and understandable" (IFRS CF QC4). Later in the text, the concept of comparability is expanded and defined as "qualitative characteristic that enables users to identify and understand similarities in, and differences among, items. Unlike the other qualitative characteristics, comparability does not relate to a single item. A comparison requires at least two items". Standard setters also note "Comparability is not uniformity. For information to be comparable, like things must look alike and different things must look different. Comparability of financial information is not enhanced by making unlike things look alike any more than it is enhanced by making like things look different" (IFRS CF Q21-23) and that "Consistency, although is related to comparability, is not the same. Consistency refers to the use of the same methods for the same items, either from period to period within a reporting entity or in a single period across entities" IFRS CF Q21-23).

Prior research by Barth et al. (2008), Barth et al. (2012), Ball (2006), and Nobes (2006) have evaluated the feasibility of convergence to IFRSs, namely potential advantages of producing more accurate, timely and complete financial information, removing international differences in accounting standards and eliminating information impediments for global capital markets. Mandatory IFRSs adoption in EU for all listed companies has provided researchers with possibility of analyzing domestic standard influence over IFRSs. Proponents of IFRSs argue that a shared set of standards would make it easier to compare the financial performance of companies across different countries, and should lead to de jure harmonization.

Arguments suggesting that mandatory IFRSs adoption is beneficial for stakeholders, comes from the premise that IFRSs reporting increases transparency and improves comparability of financial reporting. It is reflected in European Commission's justification for mandatory IFRSs:

1) The establishment of a single set of internationally accepted high quality financial reporting standards (as compared to many different local standards in force), especially for the companies listed on financial markets.

2) To contribute to the efficient and cost-effective functioning of capital market. The Commission's goals is to protect investors, by maintaining confidence in the financial markets, which would then reduce the cost of capital for firms in the EU.

3) To increase the overall global competitiveness of companies within EU and thereby improve the EU economy (Jeanjean \& Stolowy, 2008).

On the other hand, there is evidence that accounting standards play only a limited role in determining the quality of financial reporting. Because application of accounting standards involves considerable judgement and the use of private information, which allows management to have substantial discretion (Jeanjean \& Stolowy, 2008). Lang et al. (2010) compare 21 countries with mandatory IFRSs and 
conclude that earning comparability does not improve for IFRSs adopters as compared to non-adopters. Barth et al. (2008) argue that IFRSs might even reduce accounting quality for two reasons: one, IFRSs would eliminate accounting alternatives that most appropriate for specific company and second, because IFRSs is principles-based and lacks detailed implementation guidance, it affords management with greater flexibility (Ahmed et al., 2013).

Therefore, the key question is whether adoption of IFRSs leads to harmonization and better comparability of financial reports. The comparability issue is one of the major arguments for IFRSs, and is founded on belief that IFRSs reporting makes it less costly for investors to compare companies across markets and countries (Armstrong et al., 2010). Barth et al. (2008) suggest that the cost of country's investors becoming accounting experts for another country is reduced when GAAPs of the two countries become more similar, which is further supported by Horton et al. (2013), stating that analysts' forecast accuracy improves after mandatory IFRSs adoption for analysts covering companies reporting under multiple standards earlier.

The ultimate goal of IFRSs adoption and accounting systems harmonization is to provide financial markets with high quality information, improving their efficiency, lowering the cost of capital, and increasing the opportunities for capital access to companies.

\subsection{Prior studies on measurement of harmonization}

Numerous studies deal with harmonization. Tay and Parker (1990) have distinguished between de jure and de facto harmonization, defining the former as harmonization of rules and standards, and the latter as harmonization of actual practice. Van der Tas (1988) defined de jure harmonization as formal harmonization and de facto harmonization as material harmonization. The harmonization in financial reports refers to the degree of disclosure or to the accounting method applied, which is referred to as measurement harmonization.

Formal harmonization would normally lead to material harmonization (Canibano \& Mora, 2000). De facto harmonization in prior studies is measured using H-index, Cindex (van der Tas, 1988), C-index (Archer et al., 1995). Many studies have examined similarities and differences in international financial reporting, with focus on harmonization of accounting practices (Archer et al., 1995; Tay \& Parker, 1990; van der Tas, 1988) and have concluded there was a lack of harmonization in either measurement or disclosure practices within and among countries studies. Aisbitt and Nobes (2001), Hoarau (1995), Roberts et al. (2008) and Haller (2002) documented the development of de jure harmonization via EU directives and identified a shift towards convergence with IFRSs. Canibano and Mora (2000) focus on accounting practices of European "global players" using C-index and find evidence of "spontaneous harmonization" during the 1990s, but conclude that formal 
harmonization associated with Directives was not sufficient. Aisbitt (2001) uses C-index and finds evidence of harmonization between Nordic countries in 1990s, but also identifies instances of deharmonization.

Extensive research has been done on the results of IFRSs adoption globally. Mandatory adoption of IFRSs for EU listed companies from 2005 has further accelerated such research, as it has provided a unique setting, due to economic integration of countries within EU into single market. Nobes (2006) summarizes preIFRSs national accounting differences literature and raises a question whether these differences will survive after transition to IFRSs. Ball (2006) calls for caution when assuming uniformity in IFRSs based financial reports, because incentives for preparers (managers) and enforcers (auditors, courts, regulators, politicians, analysts and rating agencies) still remain local. Barth et al. (2006) provide evidence that adoption of IFRSs has improved accounting quality. Lang et al. (2010), using methodology of De Franco et al. (2011) have documented increases in earnings similarity but not accounting comparability after IFRSs adoption. They even argue that greater uniformity of IFRSs adoption may have negative effect on usefulness of accounting information, as it prohibits from taking into consideration firm, industry, and country specifics.

$\mathrm{Li}$ (2010) documents lower cost of capital for EU companies after mandatory IFRSs adoption and argues that both increased disclosure requirements and improvement in comparability contribute to her findings. Armstrong et al. (2010) argue that uniform accounting standards are likely to improve information comparability among companies, which in turn should reduce to the cost of equity capital. Armstrong et al. also propose that investors react positively to adoption of IFRSs as they expect "positive cash flow effects" (2010: 40), which result from lower cost of information obtaining and reduced possibilities for management manipulation due to greater transparency.

On the other hand, there is a fear that investors might react negatively, as they can perceive uniform IFRSs adoption as a failure to accommodate adequately regional economic, political and accounting issues (Armstrong et al., 2010). Yip and Young (2012) address the above issue by investigating 17 EU countries using three proxies for information comparability (similarity of accounting functions, degree of information transfer and similarity of information content of earnings) and conclude that comparability improvement is more likely among firms from similar institutional environments. Barth et al. (2012) used three dimensions of accounting quality (earnings smoothing, accrual quality and earnings timeliness) to evaluate comparability of IFRSs based and US GAAP based figures and have concluded, that IFRSs adoption has indeed led to greater comparability. Danske et al. (2008) provide support for IFRSs adoption through positive capital market reaction to voluntary IFRSs adoption. Ahmed et al. (2013) measure effects of IFRSs on three groups of 
accounting quality metrics: income smoothing, reporting aggressiveness, and earnings management to meet targets, and find a significant increase in aggressive reporting of accruals and no reduction in earnings-management following IFRSs adoption. Horton et al. (2013) have investigated whether increase in forecast accuracy after IFRSs adoption was attributable to higher-quality information and comparability or to the fact that IFRSs give managers greater opportunities to manipulate their earnings and thus meet the forecasts, and find that it is mainly due to earnings manipulation. In Baltic countries, accounting harmonization measurement has been discussed in Strouhal et al. (2011a; 2011b).

\subsection{Cash Flow Statement}

The balance sheet and profit or loss statement have been required statements for years, but the cash flow statement has been formally required in the United States and New Zealand only since 1988. The International Accounting Standards Board issued International Accounting Standard 7 (IAS 7) in the year 1992, and cash flow statements became integral part of financial reports for listed companies in 1994.

IAS 7 requires companies to present cash flow statement as integral part of its primary financial statements from 1994, along with balance sheet, statement of profit and loss and other comprehensive income, and statement of changes in equity. Since introduction, the cash flow statement has been a valuable tool for business valuation: owners of the company use it to analyze return on investment, managers use it to highlight strengths of companies, suppliers and creditors use it to judge payment capacity of companies. Some analysts even consider cash flow statement more important and informative than profit or loss statement, because they believe cash is less susceptible to manipulation.

According to IAS 7, the cash flow statement is prepared as follows:

Operating activities are the main revenue producing activities of the entity, and include cash received from customers and cash paid to supplies and employees (IAS 7.14).

Investing activities are the acquisition and disposal of long-term assets and other investments that are not considered cash equivalents (IAS 7.6).

Financing activities are activities and alter the equity capital and borrowing structure of the entity (IAS 7.6).

For the preparation of cash flows from operating activities section, direct method is encouraged but the indirect is also acceptable (IAS 7.35)

CFOA are interpreted as ability of company to maintain its current operations while funding future growth. Cash flows and particularly CFOA are used as a basis for business valuation, contracting, and financial analysis (Gordon et al., 2017). Extensive literature focuses on classification shifting in profit or loss statement and balance sheet, while less focus has been on classification shifting in cash flow 
statement, prior to IFRSs (Lee, 2012; Gordon et al., 2017). US GAAP requires classification of interest paid, interest received, dividends paid, and dividends received as part of operating cash flows. IFRSs, on the other hand, give financial statement preparers more flexibility and allows to classify interest paid and received and dividends received and paid as either operating, investing or financing activity, provided they are classified consistently from period to period (IAS 7.31).

Prior research indicates that format of cash flow statement is important for regulators, auditors and other users of financial statements (Hollie et al., 2011). Therefore, the effects of classification flexibility of cash flows mater as both IASB and FASB promote that financial information should enable financial statement users to assess entity's liquidity and solvency, compare performance and make predictions (Gordon et al., 2017). Several authors (Jones et al., 1995, Mills \& Yamamura, 1998) suggest that cash flow statement figures are more important than figures shown in other financial statements. Nurnberg (2006) also suggests that CFOA are important not only because they are used in fundamental analysis, but also because they are used as a measure of corporate performance that can be superior to net profit.

The importance of cash flow statement has significantly increased since accounting scandals in early $21^{\text {st }}$ century. Cash flows from operating activities are considered the most important for investors and creditors, as they come from the main revenueproducing activities and are more sustainable than cash flows from investing and financing activities (Baik et al., 2016). Atwood et al. (2011) have investigated the relationship between adoption of IFRSs and reliability of future cash flows. Their findings indicate that if IFRSs flexibility is used to disclose more private information, earnings reported under IFRSs are "more persistent and more closely associated with future cash flows than earnings reported under US GAAP" (Atwood et al., 2011, p. 107). Gordon et al. (2017) examine managerial incentives to inflate CFOA and conclude that interest paid is commonly used CFOA increasing item.

Considering prior research, it can be concluded that the net effect of adopting of IFRSs on accounting harmonization is still uncertain. The transparency and comparability arguments suggest that financial reports quality should improve. On the other hand, other influencing factors such as incentives of management and institutional factors, show that it is not necessarily the case.

\subsection{Research Gap}

This paper contributes to the international accounting research by focusing on consequences of IFRSs adoption and harmonization of financial reporting, namely effects on cash flow statement arising from different classification of interest and dividends by the listed corporations in Estonia, Latvia and Lithuania. The paper 
builds on literature for effects of mandatory IFRSs adoption on financial reporting and provides evidence that more flexible financial reporting standards are likely to increase managerial opportunism in classification shifting. It results in noncomparability of cash flow statements, thus showing that intended goal of harmonization by IFRSs has not been achieved, yet. Moreover, while majority prior research focuses on income classification shifting, this paper shows that classification shifting is also present in cash flow statement.

\subsection{Hypothesis development}

Previous research indicates that it is important to distinguish between accounting rules (de jure harmonization) and application of those rules in practice (de facto harmonization) (Wehrfritz \& Haller, 2014).

Estonia, Latvia and Lithuania are countries within a Baltic region, which have long historical and cultural connections and are often viewed as one market. After regaining of independence in 1990s, the countries carried out major economic reforms and as a result have been classified as developed economies: Estonia from year 2011, Latvia from year 2014 and Lithuania from year 2015. The countries of Estonia, Latvia and Lithuania have been rather proactive in adoption of mandatory IFRSs for listed companies, with many listed companies using early adoption option for IFRSs.

Nobes (2006) has summarized numerous reasons for national versions of IFRSs implementation practice and has provided a theoretical framework for analysis. His framework has been used in numerous empirical testing of IFRSs adoption effect both in Europe and other countries (Wehrfritz et al. (2012) on Germany vs UK; Kvaal and Nobes (2010) on Australia, France, Germany, Spain and UK; Zeff and Nobes (2010) on Australia; Baik et al. (2016) on Korea). As Baltic countries were not included in such research previously, Nobes (2006) and Nobes (2013) framework will be used for hypothesis development. Nobes (2006) identifies the following major causes for lack of harmonization under IFRSs: (1) Different versions of IFRSs due to different endorsement, (2) different translations of IFRSs, (3) Gaps in IFRSs, (4) Explicit options in IFRSs, (5) Covert options in IFRSs, (6) transition or first-time adoption of IFRSs and (8) imperfect enforcement of IFRSs. In case of Estonia, Latvia and Lithuania, public companies are traded on the joint stock exchange, thus information requirements form capital markets are the same. All three countries are member states of the EU, thus same directives concerting IFRSs have been adopted. As of 2003, IFRSs have been permitted to be used by almost all business entities in Estonia. From January 1, 2005, IFRSs have been mandatory for all listed companies, credit and financial institutions, insurance companies (Alver \& Alver, 2017). Lithuania and Latvia have mandatory IFRSs for listed companies from 2005. 
Similarity of counties is further supporter by Borker IFRSs orientation index. Borker (2015) has developed a IFRSs orientation index, based on Hofstede's Four Dimensions and Gray Accounting values. According to his findings Estonia, Latvia and Lithuania are rather similar, with Estonia and Latvia scoring 67 points, while Lithuania 64, which places countries along Sweden, Finland and Germany (Borker, 2015).

In view of the above, hypothesis of the paper is:

There is harmonization in cash flow statements within and among listed Baltic States' companies.

To achieve the aim of the article, the authors have raised the following research questions:

- What choices companies make for presentation formats of cash flow statement?

- What choices companies make for classification of interest received and interest paid?

- What choices companies make for classification of dividend received and dividend paid?

\section{Research methodology}

To quantify the degree of uniformity of practices adopted by companies, C-index proposed by van der Tas (1988) has been applied. The use of the index implies that maximum harmony is reached when all the companies in the sample select the same alternative. For purposes of this study a sample of is $100 \%$ of listed companies on Baltic Nasdaq is used, which eliminates the bias of sample over population (Taplin, 2011). These are companies with very similar characteristics as they operate in international context and the characteristics of users of their financial statements are similar independently of their national context. For this purpose, C-index is considered as the most suitable for the measurement of harmony level. Following Archer et al. $(1995,1996)$ C-index is broken down to within-country and betweencountry indices.

\subsection{Data collection and Sample}

Research population consisted of 33 public companies. The sample contains all companies that are listed on Nasdaq Baltic market, which includes stock exchanges in Tallinn, Riga and Vilnius. For each observation in the sample, financial statements of the company are retrieved from NASDAQ website (www.nasdaqbaltic.com) for years 2010-2017. The period allows eliminating extraordinary classification due to mandatory first time adoption of IFRSs and also allows observing consistency of classification items in cash flow statements. 
Data was sourced from secondary sources: Annual Consolidated Financial Statements of companies, namely Cash Flow Statements.

Estonia: 100\% listed companies, 15 in total.

Latvia: $100 \%$ listed companies, 5 in total.

Lithuania: 100\% listed companies, 13 in total.

In general, companies in such specific sectors as banking and insurance are subject so specific treatments. Therefore, two financial institutions, LHV Group in Estonia and Šiauliu Bankas in Lithuania have been excluded from the sample, leaving 31 observations.

The accounting issues selected for harmonization measurement were: format of cash flow statement, interest paid and received classification, dividends paid and received classification. The reason for selecting these specific issues is largely due to the fact that they are considered among the most controversial in terms of comparability of cash flow statements (Alver, 2004; Alver, 2005; Alver \& Alver, 2011a; Alver \& Alver, 2011b; Atwood et al., 2011; Baik et al., 2016; Barth et al., 2012; Bradbury, 2011; Istrate, 2015; Gordon et al., 2017; Hollie et al., 2011).

\section{Results and Discussion}

One way to compare financial statements is to measure the extent of similarities of differences between them, which would allow drawing conclusions, which statements are most alike and which are most different. The comparability in accounting methods used increases, as companies concentrate more on one alternative method, and Herfindahl or H-index (Roberts, et al., 2008) can measure this concentration.

$\mathrm{H}$-index is:

$$
\sum_{i=1}^{n} p_{i}^{2}
$$

where: $\mathrm{p}_{\mathrm{i}}-$ the proportion of companies using accounting method $i$;

$\mathrm{n}$ - the maximum number of possible methods that can be used.

$\mathrm{H}$-index can vary from low $1 / \mathrm{n}$ when companies use various methods, to a high of 1.00 when all companies use the same method. The downside of H-index is that is does not provide information on one-to-one relationship between popularity of alternative methods, thus interpretation could be ambiguous.

C-index, developed by van der Tas in 1992 and adjusted by Archer et al. in 1995, considers proportion of companies that use each accounting method and thus looks at a number of financial statements that are compatible with each other (Roberts, 2008). 
C-index is:

$$
\frac{\sum\left(n_{i} \times\left(n_{i}-1\right)\right)}{N \times(N-1)},
$$

where: $n_{i}-$ number of companies using method $i$

$\mathrm{N}$ - the total number of companies.

The basic C-index measures direct comparability of reported accounting numbers which are treated as comparable only if the same accounting method is used by any two companies and does not take into account supplementary information which may assist the user to make adjustments to achieve comparability (Archer et al., 1995).

Both H-index and C-index are popular measures of comparability, or harmony, of financial reports. C-index can be used to measure international harmony, defined as comparability of financial reports regardless of country of origin (called "betweencountry" harmonization). It provides answers to questions regarding harmonization level in one country as well as to what extent financial reports are compatible from one county to another.

\subsection{Format of Cash Flow Statement}

Cash flows from operating activities section can be prepared using either direct method (showing cash inflows and outflows) or indirect method (methodologically reversing effects of accruals from the net profit, using information from profit or loss statement and balance sheet). Both IASB and FASB consider direct method as preferred and while most jurisdictions allow the option of either direct or indirect method, majority of companies choose indirect method of presentation (Bradbury, 2011).

Table 1. Format of Cash Flow Statement

\begin{tabular}{lrrrr}
\hline \multirow{2}{*}{\multicolumn{1}{c}{ Country }} & \multicolumn{2}{c}{ Direct method } & \multicolumn{3}{c}{ Indirect method } \\
\cline { 2 - 5 } & No of Firms & $\%$ & No of Firms & \% \\
\hline Estonia & 3 & $21 \%$ & 11 & $79 \%$ \\
Latvia & 0 & $0 \%$ & 5 & $100 \%$ \\
Lithuania & 0 & $0 \%$ & 12 & $100 \%$ \\
C-index & & & & \\
Overall & 0.81 & & & \\
Within-country & 0.81 & & & \\
Between-country & 0.77 & & & \\
\hline
\end{tabular}

Table 1 compares the formats chosen for cash flow statement. As can be seen, 100\% of companies in Lithuania and Latvia use indirect method, while in Estonia $21 \%$ use direct method and $79 \%$ indirect method. C-index is rather high, with majority of companies preferring indirect method. 


\subsection{Classification issues}

Appendix 1 summarizes classification of interest received and interest paid, dividends received and dividends paid among Operating, Investing and Financial Activities by Baltic listed companies. Based on the data, $\mathrm{H}$-index for harmonization is shown in Table 2 .

Table 2. H-index for Baltic Countries

\begin{tabular}{lcccc}
\hline Country/H-index & IntR & IntP & DivR & DivP \\
\hline Estonia & 0.76 & 0.50 & 0.72 & 1.00 \\
Latvia & 0.52 & 0.52 & 1.00 & 1.00 \\
Lithuania & 0.72 & 0.50 & 1.00 & 1.00 \\
\hline
\end{tabular}

Table 2 provides country specific harmonization levels measured with $\mathrm{H}$-index for each category. As can be seen, there is a high level of country wise harmonization of dividend treatment, while not so in interest classification. To understand whether such classification pattern could be influenced by national standards, Table 3 provides national standard requirements (pre-IFRSs) for classification of interest and dividends in each of the countries.

Table 3. National requirements for classification on Cash Flow Statement

\begin{tabular}{llll}
\hline Country & \multicolumn{1}{c}{ CFOA } & \multicolumn{1}{c}{ CFIA } & \multicolumn{1}{c}{ CFFA } \\
\hline Estonia & Interest paid & Interest received & Dividends paid \\
& & Dividends received & \\
Latvia & Interest paid & Interest received & Dividends paid \\
& & Dividends received & \\
Lithuania & & Interest received & Dividends paid \\
& & Dividends received & Interest paid \\
\hline
\end{tabular}

Classification results show partial correlation with pre-IFRSs requirements for listed companies. Estonia and Latvia have permitted interest paid to be recorded only in CFOA, while currently $57 \%$ and $40 \%$ of companies choose this option. In Lithuania, on the other hand, national standards have required interested paid to be classified as cash flows from financing activities (CFFA) only. Currently, only $42 \%$ of companies are using this option, while $58 \%$ of companies have shifted classification to CFOA. It show a major shift of classification with IFRSs adoption. All three countries have required classifying interest and dividends received as cash flows from investing activities (CFIA).

Results in Appendix 1 show significant shifts in classification of interest received in all countries, especially Latvia (with $40 \%$ using CFOA option). Dividends received, continue to be mostly classified as CFIA, resulting in high $\mathrm{H}$-index and following historical treatment. Under national standards, dividends paid could be classified only as CFFA and companies continue to use this option, with perfect harmony of $1.0 \mathrm{H}$-index. 
Therefore, it can be concluded, that IFRSs based financial statements of Baltic listed companies, do not follow historical traditions for classification of interest paid and received, while dividends received and paid are classified more persistently over time. The following sections will provide a more detailed analysis of classification issues and harmony measurement using C-index for both within-country and between-country harmonization level.

\subsubsection{Interest received classification}

Table 4. Classification of Interest received

\begin{tabular}{lcccccc}
\hline \multicolumn{1}{c}{ Country } & \multicolumn{2}{c}{ Operating Activities } & \multicolumn{2}{c}{ Investing Activities } & \multicolumn{2}{c}{$\begin{array}{c}\text { Financing } \\
\text { Activities }\end{array}$} \\
\hline Estonia & 3 & $21 \%$ & 11 & $79 \%$ & 0 & $0 \%$ \\
Latvia & 2 & $40 \%$ & 3 & $60 \%$ & 0 & $0 \%$ \\
Lithuania & 3 & $25 \%$ & 9 & $75 \%$ & 0 & $0 \%$ \\
C-index & & & & & & \\
$\begin{array}{l}\text { Overall } \\
\text { Within-country }\end{array}$ & 0.68 & & & & \\
Between- \\
country
\end{tabular}

As can be seen from Table 4, interest received classification varies among each country, with Estonian and Lithuanian companies heavily leaning towards classifying interest received to CFIA ( $80 \%$ and $75 \%$ respectively) and CFOA (33\% and $25 \%$ ). While in Latvia, it is more evenly dispersed, with CFOA classification by $40 \%$ CFIA classification by $60 \%$. This distribution also shows that Lithuanian companies are far more likely to allocate interest received over different cash flow categories, as 7 companies out of 12 have interest received in both Operating and Investing Cash Flows. In Estonia, only 3 out of 14 companies use this approach, while in Latvia, 1 out of 5 . None of the companies in the sample has have classified interest received as part of financing activities. Different approaches used are reflected in C-index, with within-country harmony being rather high, but dropping significantly at between-country level. Companies in Estonia, Latvia and Lithuania are using different treatment for interest received classification on cash flow statement and harmony index is low.

\subsubsection{Interest paid classification}

Table 5. Classification of Interest paid

\begin{tabular}{|c|c|c|c|c|c|c|}
\hline Country & \multicolumn{2}{|c|}{$\begin{array}{l}\text { Operating } \\
\text { Activities }\end{array}$} & \multicolumn{2}{|c|}{$\begin{array}{l}\text { Investing } \\
\text { Activities }\end{array}$} & \multicolumn{2}{|c|}{$\begin{array}{l}\text { Financing } \\
\text { Activities }\end{array}$} \\
\hline Estonia & 8 & $57 \%$ & 0 & $0 \%$ & 6 & $43 \%$ \\
\hline Latvia & 2 & $40 \%$ & 0 & $0 \%$ & 3 & $60 \%$ \\
\hline Lithuania & 7 & $58 \%$ & 0 & $0 \%$ & 5 & $42 \%$ \\
\hline \multicolumn{7}{|l|}{ C-index } \\
\hline Overall & 0.48 & & & & & \\
\hline Within-country & 0.46 & & & & & \\
\hline Between-country & 0.25 & & & & & \\
\hline
\end{tabular}


Table 5 shows than in reference to interest paid classification, companies lean towards classifying it as either CFOA or CFFA, while none allocate it to investing activities. In this section, Estonian and Lithuanian companies show similar trends, with 57-58\% allocating it to CFOA and $43-42 \%$ to CFFA, resulting in average within-country C-index of 0.46 . While in Latvia, proportions are reversed, with more companies allocating interest paid to CFFA. This is reflected by significantly lower between-country C-index of 0.25. Companies in Estonia, Latvia and Lithuania are using different treatment for interest paid classification on cash flow statement and between-country harmony index is low.

\subsubsection{Dividends received classification}

Table 6. Classification of Dividends received

\begin{tabular}{lcccccc}
\hline \multicolumn{1}{c}{ Country } & $\begin{array}{c}\text { Operating } \\
\text { Activities }\end{array}$ & \multicolumn{2}{c}{ Investing Activities } & \multicolumn{2}{c}{$\begin{array}{c}\text { Financing } \\
\text { Activities }\end{array}$} \\
\hline Estonia & 0 & $0 \%$ & 4 & $29 \%$ & 1 & $7 \%$ \\
Latvia & 0 & $0 \%$ & 1 & $20 \%$ & 0 & $0 \%$ \\
Lithuania & 0 & $0 \%$ & 9 & $75 \%$ & 0 & $0 \%$ \\
C-index & & & & & & \\
Overall & 0.88 & & & & \\
Within-country & 0.90 & & & & \\
Between-country & 0.83 & & & & \\
\hline
\end{tabular}

Table 6 provides summary of dividends received classification. Before looking at differences in dividend received classification, it should be noted that frequency of such income is rather different among countries; in Estonian sample 36\% of firms (5 out of 14) had dividend income, in Latvia - none, in Lithuania - 75\% (9 out of 12 firms). Therefore if to restate the figures to the firms having actual dividend income, in Estonia $80 \%$ (4 out of 5) classify dividends received as CFIA and 20\% as CFFA (1 out of 5), none use CFOA option. While in Lithuanian sample all 100\% classify dividends received as CFIA. Resulting C-index supports that harmonization is achieved as to dividends received classification.

Companies in Estonia, Latvia and Lithuania are using different treatment for dividends received classification on cash flow statement, but with most companies clustering in investing activities. Thus, harmonization level is high.

\subsubsection{Dividends Paid classification}

Table 7. Classification of Dividends paid

\begin{tabular}{lcccrrr}
\hline \multicolumn{1}{c}{ Country } & $\begin{array}{c}\text { Operating } \\
\text { Activities }\end{array}$ & \multicolumn{2}{c}{ Investing Activities } & \multicolumn{2}{c}{$\begin{array}{c}\text { Financing } \\
\text { Activities }\end{array}$} \\
\hline Estonia & 0 & $0 \%$ & 0 & $0 \%$ & 14 & $100 \%$ \\
Latvia & 0 & $0 \%$ & 0 & $0 \%$ & 5 & $100 \%$ \\
Lithuania & 0 & $0 \%$ & 0 & $0 \%$ & 12 & $100 \%$ \\
C-index & & & & & & \\
Overall & 1.00 & & & & \\
Within-country & 1.00 & & & & & \\
Between-country & 1.00 & & & & & \\
\hline
\end{tabular}

Vol. 18, No. 3 
Dividends paid is the only homogenous area of classification by Baltic listed companies - all classified dividends paid as CFFA. Thus, C-index is a perfect 1.00 at both within- and between-country level.

As noted in previous sections, Conceptual Framework stresses that "consistency, although is related to comparability, is not the same. Consistency refers to the use of the same methods for the same items, either from period to period within a reporting entity or in a single period across entities" (IFRS CF Q21-23). The results of study show that there is a longitudinal consistency of classification by observed companies for all items under analysis: format of cash flow statement, interest received, interest paid, dividends received and dividends paid. During the period of observation, some companies have changed classification for some items, but have thereafter been consistent. For example, AB Lietuvos Energijos Gamyba has reclassified dividends received from CFFA to CFIA in 2012; AS Tallinna Vesi has reclassified interest paid from CFOA to CFFA in 2012. An interesting shift has occurred in AS Merko Ehitus, company, which has shifted interest received classification from CFIA and now classifies it over two activities: CFOA and CFIA.

Both dividends received and dividends paid classification has achieved a high level of harmony intended by IFRSs. However, interest paid and interest received treatment despite de jure harmonization of the standard, has not resulted in de facto harmonization.

\section{Conclusion}

Harmonized accounting standards do not necessarily lead to harmonized accounting outcomes, if preparers have flexibility in the application. Country-specific factors may have effect on variation seen in IFRSs reporting across Baltic countries. In this study, variations in preparation and classification of cash flow statement by listed companies on Baltic Nasdaq have been examined. Results have revealed the lack of homogeneity in various accounting areas and show partial support for national variances in IAS 7 application for cash flow statement.

Therefore, IAS 7 flexibility in choices for classification is a two side issue: on one hand, it should allow for higher quality financial reporting as managers can incorporate for company specific factors; on the other hand, it reduces comparability of reports among the companies.

This paper contributes to the accounting literature analyzing the consequences of IFRSs adoption and reporting. Considering, that more than 120 countries have already adopted IFRSs, this research has practical application for the business analysts and international investors. The results show that classification flexibility allowed under IAS 7 has been used by Baltic Main List companies and has increased 
variation in classification of interest and dividend received and paid. Further research could focus on the actual effects of such classification flexibility on the cash flow ratios.

Even if IFRSs are adopted everywhere, there will still be political, cultural and regulatory influences, which can result in inconsistent application of accounting standard from one country to another (Grossman et al., 2013). Convergence de facto is still less certain than convergence de jure, especially for principles based standards like IFRSs (Ball, 2006).

Users of financial statements find cash flow statement to be useful, especially in getting information how cash, a vital resource to a business entity, comes into company and how it is utilized (Petty \& Rose, 2009). The results of current study show that harmonization has been achieved only for some issues under investigation, like format of cash flow statement, dividends paid and dividends received. Interest paid and interest received classification has not been harmonized yet. Thus, users of financial reports should not assume full comparability of cash flow statements for Estonian, Latvian and Lithuanian firms, despite a single stock exchange, cultural and economic similarities and de jure harmonization of accounting standards.

The results of current study show that users of financial reports cannot expect comparability of cash flow statements for Estonian, Latvian and Lithuanian companies, despite the existence of a single stock exchange, cross-border cultural and economic similarities of countries. Future research should focus on the significance of such classification variances on financial ratios, and in particular, on cash flow ratios, as integration of cash flow data with traditional ratios could provide a superior measure of performance over accrual accounting data alone.

\section{References}

Ahmed, A., Neel, M. \& Wang, D. (2013) „Does mandatory adoption of IFRS improve accounting quality? Preliminary Evidence", Contemporary Accounting Research, vol. 30, no. 4: 1322-1372

Aisbitt, S. (2001) „Measurement of harmony of financial reporting within and between countries: the case of the Nordic countries", European Accounting Review, vol. 10, no. 1: 51-72.

Aisbitt, S. \& Nobes, C. (2001) ,The true and fair view requirement in recent national implementations", Accounting and Business Research, vol. 31, no. 2: 83-90

Albu N. \& Albu, C.-N. (2014) „Editorial - IFRS application in Central and SouthEastern European countries", Accounting and Management Information Systems, vol. 13, no. 2: 182-197 
Alver, J. (2004) „On some problems of preparation and analysis of cash flow statements", Acta Universitatis Latviensis, vol. 677, Economics and Management: 9-15.

Alver, J. (2005) „Preparation and analysis of cash flow statements: the net profit approach and operating profit approach", Tallinn University of Technology, School of Economics and Business Administration, Working Papers in Economics, vol. 15: 39-52.

Alver, J. \& Alver, L. (2011a) Majandusarvestus ja rahandus: Leksikon I, A-L. Tallinn: Deebet.

Alver, J. \& Alver, L. (2011b) Majandusarvestus ja rahandus: Leksikon II, M-Y. Tallinn: Deebet.

Alver, L. \& Alver, J. (2017) „The role and current status of IFRS in the completion of the National Accounting Rules - Evidence from Estonia", Accounting in Europe, no. 14: 80-87

Annual reports of companies. Available from internet: http://www.nasdaqbaltic. $\mathrm{com} / \mathrm{market} / \mathrm{pg}=$ mainlist\&lang=en (access 10 January 2019)

Archer, S., Delvaille, P. \& McLeay, S. (1995) „The measurement of harmonization and the comparability of financial statement items: within-country and between-country effects", Accounting and Business Research, vol. 25, no. 98: 67-80

Archer, S., Delvaille, P. \& McLeay, S. (1996) „A statistical model of international accounting harmonization", Abacus, vol. 32, no. 1: 1-29

Armstrong, C., Barth, M., Jagolinzer, A. \& Riedl, E. (2010) „Market reaction of the adoption of IFRS in Europe", The Accounting Review, vol. 85, no. 1: 31-61

Atwood, T., Drake, M., Myers, J. \& Myers, L. (2011) „Do earnings reported under IFRS tell us more about future earnings and cash flows?", Journal of Accounting and Public Policy, vol. 30: 103-121

Baik, B., Cho, H., Choi, W. \& Lee, K. (2016) „Who classifies interest payments as financing activities? An analysis of classification shifting in the statement of cash flows after the adoption of IFRS", Journal of Accounting and Public Policy, vol. 35: 331-351

Baker, C. \& Barbu, E. (2007) „Evolution of research on international accounting harmonization: a historical and institutional perspective", Socio-Economic Review, no. 5: 603-632

Ball, R. (2006) „International Financial Reporting Standards (IFRS): pros and cons for investors", Accounting and Business Research, 5-7

Barth, M., Landsman, W. \& Lang, M. (2008) „International Accounting Standards and Accounting Quality", Journal of Accounting Research, vol. 46, no 3: 467-498

Barth, M., Landsman, W., Lang, M. \& Williams, C. (2012) „Are IFRS-based and US GAAP-based accounting amounts comparable?", Journal of Accounting and Economics, vol. 54: 68-93

Borker, D. (2015) „Sociocultural IFRS value analysis in Estonia, Latvia and Lithuania", The Business and Management Review, vol. 6, no. 2: 281-289

Bradbury, M. (2011) „Direct or Indirect Cash Flow Statements?”, Australian Accounting Review, no. 57, vol. 21: 124-130 
Canibano, L. \& Mora, A. (2000) „Evaluating the statistical significance of de facto accounting harmonization: a study of European global plyers", European Accounting Review, vol. 9, no. 3: 349-369

Danske, H., Hail, L., Leuz, C. \& Verdi, R. (2008) „Mandatory IFRS Reporting around the World: Early Evidence on the Economic Consequences”, Journal of Accounting Research, vol. 46, no. 5: 1085-1142

De Franco, G., Kothari, S. P. \& Verdi, R. (2011) „,The Benefit of Financial Statement Comparability", Journal of Accounting Research, vol. 49, no. 4: 895-931

Gordon, E., Henry, E., Jorgensen, B. \& Linthicum, Ch. (2017) „Flexibility in cashflow classification under IFRS: determinants and consequences", Review of Accounting Studies, vol. 22 (2): 839-872

Grossman, A., Smith, L. \& Tervo, W. (2013) „Measuring the impact of international reporting standards on market performance of publicly traded companies", Advances in Accounting, incorporating Advances in International Accounting, vol. 29: 343-349

Haller, A. (2002) „Financial accounting developments in the European Union: past events and future prospects", European Accounting Review, vol. 11, no. 1: $153-190$

Hoarau, C. (1995) „International accounting harmonization: American hegemony or mutual recognition with benchmarks?", European Accounting Review, vol. 4, no. 2: 217-233

Hollie, D., Nicholls, C. \& Zhao, Q. (2011) „Effects of cash flow statement reclassifications pursuant to the SEC's one-time allowance", Journal of Accounting and Public Policy, vol. 30 (6): 570-588

Horton, J., Serafeim, G. \& Serafeim, I. (2013) „Does mandatory IFRS adoption improve the information environment?" Contemporary Accounting Research, vol. 30, no. 1: 388-423

IFRS (2018) IAS 7 - Statement of Cash Flows. Available from internet: https://www.iasplus.com/en/standards (access 10 December 2018)

IFRS (2019) IFRS Conceptual Framework. Available from internet: http://www.ifrs.org/projects/work-plan/conceptual-framework/ (access 10 January 2019)

Istrate, C. (2015) „The persistence of the accounting policies after the transition to IFRS of the Romanian listed companies", Accounting and Management Information Systems, vol. 14, no. 4: 599-626

Jeanjean, T. \& Stolowy, H. (2008) „Do accounting standards matter? An exploratory analysis of earnings management before and after IFRS adoption", Journal of Accounting and Public Policy, vol. 27: 480-494

Jones, S., Romano, C. \& Smyrnios, K. (1995) „An Evaluation of the Decision Usefulness of Cash Flow Statements by Australian Reporting Entities", Accounting and Business Research, vol. 25, no. 98: 115-129

Kvaal, E. \& Nobes, C. (2010) „International differences in IFRS policy choice: A research note", Accounting and Business Research, vol. 40, no. 2: 173-187

Mills, J. \& Yamamura, J. (1998) „The power of cash flow ratios”, Journal of Accountancy, vol. 186, no. 4: 53-61

Lang, M., Maffett, M., \& Owens, E. (2010) „Earnings comovement and accounting comparability: The effects of mandatory IFRS adoption", Simon School 
Working Paper No. FR 11-03. Available at SSRN: https://ssrn.com/abstract=1676937 or http://dx.doi.org/10.2139/ssrn.16769 37 (access 10 December 2018)

Lee, T. A. (2012) ,Incentives to inflate reported cash from operations using classification and timing", The Accounting Review, vol. 87, no. 1: 1-33

Li, S. (2010) „Does mandatory adoption of international financial reporting standards in European Union reduce the cost of equity capital?", The Accounting Review, vol. 85, no. 2: 607-636

Nobes, C. (2006) „The survival of international differences under IFRS: towards research agenda", Accounting and Business Research, vol. 36, no. 3: 233-245

Nobes, C. (2013) „The continued survival of international differences under IFRS”, Accounting and Business Research, vol. 43, no. 2: 83-111

Nurnberg, H. (2006) ,The distortion effects of acquisitions and dispositions on net operating cash flows", Accounting Forum, vol. 30: 209-226

Petty, J. \& Rose, J. (2009) „Free cash flow, the cash flow identity, and the accounting statement of cash flows", Journal of Financial Education, vol. 35: 41-55

Roberts, C., Weetman, P. \& Gordon, P. (2008) International Corporate Reporting: a comparative approach, $4^{\text {th }}$ edition, UK: Prentice Hall

Strouhal, J., Bonaci, C., Mustata, R., Alver, L., Alver, J. \& Praulins, A. (2011a) „Accounting Harmonization Measurement: Case of Emerging CEE Countries", International Journal of Mathematical Models and Methods in Applied Sciences, vol. 5, no. 5: 899-906

Strouhal, J., Albu, C., Albu, N., Alver, J., Alver, L., Blechova, B., Bonaci, C., Dvorakova, D., Girbina, M., Kazlauskiene, L., Mackevicius, J., Mustata, R., Pasekova, M., Praulins, A. \& Zverovich, S. (2011b) Harmonization of SME's Financial Reporting in Emerging CEE Countries, Stevens Point: WSEAS Press

Taplin, R. (2011) „The measurement of Comparability in Accounting Research”, Abacus, Vol. 47, no. 3: 383-409

Tas van der, L. (1988) „Measuring Harmonization of Financial Reporting Practice”, Accounting and Business Research, vol. 18, no. 70: 157-169

Tay, J. \& Parker, R. (1990) „Measuring international harmonization and standardization", Abacus, vol. 26, no. 1: 71-88

Wehrfritz, M., \& Haller, A. (2014) „National influence on the application of IFRS: Interpretations and accounting estimates by German and British accountants", Advances in Accounting, Incorporating Advances in International Accounting, vol. 30: 196-208

Yip, R. \& Young, D. (2012) „Does mandatory IFRS adoption improve information comparability?" The Accounting Review, vol. 87, no. 5: 1767-1789

Zeff, S., \& Nobes, C. (2010) „Commentary: Has Australia (or any other jurisdiction) “adopted” IFRS?", Australian Accounting Review, no. 53, vol. 20: 178-184 
Appendix 1. Classification of Interest received, Interest paid, Dividends received and Dividends paid

\begin{tabular}{|c|c|c|c|c|c|c|c|c|c|c|c|c|}
\hline \multirow[t]{2}{*}{ Country } & \multicolumn{4}{|c|}{$\begin{array}{c}\text { Cash Flows from } \\
\text { Operating Activities } \\
\text { (CFOA) }\end{array}$} & \multicolumn{4}{|c|}{$\begin{array}{c}\text { Cash Flows from } \\
\text { Investing Activities } \\
\text { (CFIA) }\end{array}$} & \multicolumn{4}{|c|}{$\begin{array}{c}\text { Cash Flows from } \\
\text { Financing Activities } \\
\text { (CFFA) }\end{array}$} \\
\hline & $\begin{array}{l}\text { Int } \\
\mathbf{R}\end{array}$ & $\begin{array}{l}\text { Int } \\
P\end{array}$ & $\begin{array}{l}\text { Div } \\
\text { R }\end{array}$ & $\begin{array}{l}\text { Div } \\
\text { P }\end{array}$ & $\begin{array}{l}\text { Int } \\
\mathbf{R}\end{array}$ & $\begin{array}{l}\text { Int } \\
P\end{array}$ & $\begin{array}{l}\text { Div } \\
\text { R }\end{array}$ & $\begin{array}{l}\text { Div } \\
\text { P }\end{array}$ & $\begin{array}{l}\text { Int } \\
\mathbf{R}\end{array}$ & $\begin{array}{l}\text { Int } \\
P\end{array}$ & $\begin{array}{l}\text { Div } \\
\mathbf{R}\end{array}$ & $\begin{array}{l}\text { Div } \\
\text { P }\end{array}$ \\
\hline \multirow[t]{2}{*}{ Estonia } & 3 & 8 & 0 & 0 & 11 & 0 & 4 & 0 & 0 & 6 & 1 & 14 \\
\hline & $\begin{array}{l}21 \\
\%\end{array}$ & $\begin{array}{l}57 \\
\%\end{array}$ & $0 \%$ & $0 \%$ & $\begin{array}{l}79 \\
\%\end{array}$ & $0 \%$ & $29 \%$ & $0 \%$ & $0 \%$ & $\begin{array}{l}43 \\
\%\end{array}$ & $7 \%$ & $\begin{array}{l}100 \\
\%\end{array}$ \\
\hline \multirow[t]{2}{*}{ Latvia } & 2 & 2 & 0 & 0 & 3 & 0 & 1 & 0 & 0 & 3 & 0 & 5 \\
\hline & $\begin{array}{l}40 \\
\%\end{array}$ & $\begin{array}{l}40 \\
\%\end{array}$ & $0 \%$ & $0 \%$ & $\begin{array}{l}60 \\
\%\end{array}$ & $0 \%$ & $20 \%$ & $0 \%$ & $0 \%$ & $\begin{array}{l}60 \\
\%\end{array}$ & $0 \%$ & $\begin{array}{l}100 \\
\%\end{array}$ \\
\hline \multirow{2}{*}{$\begin{array}{l}\text { Lithuan } \\
\text { ia }\end{array}$} & 3 & 7 & 0 & 0 & 9 & 0 & 9 & 0 & 0 & 5 & 0 & 12 \\
\hline & $\begin{array}{l}25 \\
\%\end{array}$ & $\begin{array}{l}58 \\
\%\end{array}$ & $0 \%$ & $0 \%$ & $\begin{array}{l}75 \\
\%\end{array}$ & $0 \%$ & $75 \%$ & $0 \%$ & $0 \%$ & $\begin{array}{l}42 \\
\%\end{array}$ & $0 \%$ & $\begin{array}{l}100 \\
\%\end{array}$ \\
\hline
\end{tabular}

Where:

Source: Compiled by the authors from companies' annual reports

IntR - Interest received

IntP - Interest paid

DivR - Dividends received

DivP - Dividends paid 